\title{
ICU入室中患者の死亡月に関する検討
}

\author{
編集委員長殿
}

本誌第 18 巻第 3 号に掲載された田口1)の調査報告 $\lceil\mathrm{ICU}$ 入室中の患者の死亡月と時刻に関する時間的法 則性についての実態調査」を興味深く帱読致しまし た。著者は主としてサーカディアンリズムに代表され る死亡の日内変動に大きな興味を持っている印象を受 けましたが, 我々は死亡月に関して, 夏季と冬季にピー クが存在した結果に注目しております。

これまでにも一般的な傾向として冬季に死亡率が上 昇することは知られてきましたが2),3), Harrison ら4) は 英国に扔けるICU内の治療患者に関しても冬季の死 亡率上昇を報告しており，ICU入室時の重症度で補正 しても, 季節性の変動が統計学的に認められます。 Reinikainen ら ${ }^{5)}$ はフンランドのICUにおける死亡 率の季節性変化を調查し, やはり冬季における死亡率 の上昇を確認していますが，同時に，7月に突出した 死亡率のピークが存在したことを報告しています。こ の結果は, 田口尚の死亡月に関する検討とほぼ一致し ます。

Reinikainen ら ${ }^{5)}$ は 7月の死亡率突出について, 夏季 休暇期間との関係を考察しています。休㗇取得者の増 加に伴い, 救急外来や病棟の熟練した医療スタッフが 減少するため, ICUへ入室して加療を開始するまでに 平時より長い時間を要する可能性を仮説として取り上 げています5)。本邦の医療機関に扔いても，夏季休㗇 取得のほか, 冬季には年末年始の長期間休診が一般的 に定着しており，影響は少なくないと考えられます。 田口1)の結果からは, 熟練者が最も多いと考えられる 年度末の 3 月に死亡者が最少となり, 新年度の 4 月に 上昇する傾向がみてとれます。

ICUはその特性から人的資源を多く必要とし 11,6$)$, そ の管理体制や運営方針に関しては日本集中治療医学会 による調查が行われていますが7), 今後, さらに多く の研究, 検討が必要と思われます。

本稿の全ての著者には規定されたCOIはない。
足立 裕史*1, 松田 直之 $* 1,2$

*1名古屋大学医学部附属病院救急部

$* 2$ 名古屋大学大学院医学系研究科救急 - 集中治療医学 分野

（４ 466-8550 愛知県名古屋市昭和区鶴舞町 65）

文 献

1) 田口豊恵. ICU入室中の患者の死亡月と時刻に関する時間 的法則性についての実態調査. 日集中医誌 2011;18:429-32.

2) Sheth T, Nair C, Muller J, et al. Increased winter mortality from acute myocardial infarction and stroke: the effect of age. J Am Coll Cardiol 1999;33:1916-9.

3) Keatinge WR. Winter mortality and its causes. Int J Circumpolar Health 2002;61:292-9.

4) Harrison DA, Lertsithichai P, Brady AR, et al. Winter excess mortality in intensive care in the UK: an analysis of outcome adjusted for patient case mix and unit workload. Intensive Care Med 2004;30:1900-7.

5) Reinikainen M, Uusaro A, Ruokonen E, et al. Excess mortality in winter in Finnish intensive care. Acta Anaesthesiol Scand 2006;50:706-11.

6) Myotoku M, Iwamoto C, Tomida $\mathrm{Y}$, et al. Introduction and evaluation of a newly established holiday work system in the ward pharmacy at Municipal Ikeda Hospital. Yakugaku Zasshi 2006;126:1003-10.

7) 日本集中治療医学会ICU 機能評価委員会, 平成 20 年度厚 生労働科学研究班. ICUの人員配置と運営方針が予後に与 える影響について．日集中医誌 2011;18:283-94.

受付日 2012 年 7 月 17 日 採択日 2012 年 7 月 20 日

\section{The insight for mortality regarding the month in ICU patients}

To the Editor: Yushi Adachi*1, Naoyuki Matsuda*1,2

${ }^{* 1}$ Department of Emergency Medicine, Nagoya University Hospital

${ }^{* 2}$ Department of Emergency and Critical Care Medicine, Nagoya University Graduate School of Medicine (65 Tsurumai-cho, Showa-ku, Nagoya, Aichi 466-8550, Japan) 